\title{
Significance of Further Professional Education in Continuing Vocational Education System
}

\author{
Dmitry L. Matukhin* \\ National Research Tomsk Polytechnic University \\ 30 Lenin, Tomsk, 634050, Russia
}

Received 04.10.2014, received in revised form 30.11.2014, accepted 21.12.2014

\begin{abstract}
Article deals with problems of further professional education which is regarded from the perspective of domestic and western understanding of the concept of lifelong education. The development of further professional education as part of continuing vocational education is very topical for Russia. This is due to conjunctural changes of personnel policy in the labor market, dynamic changes in the educational market, computerization of society and Russia's desire to turn to innovative way of development.
\end{abstract}

Keywords: further professional education, continuing vocational education, human capital, labor market, retraining.

Research area: philology.

\section{Introduction}

When developing human capital, dominant role refers to educational institution. However, one should take into account the fact that human capital is subject to obsolescence. Quick change of investigation forms and methods, sharp reduction in terms of introduction new scientific discoveries and technological inventions pose actual problem of obsolescence of knowledge received by graduates of all educational institutions and, consequently, human capital.

Accelerating obsolescence of human capital, emergence of demand for mass professionals of a completely different specialization needs to respond quickly to changes in the list of occupations and professions, and as soon as possible to meet demand for new professionals. In the U.S., for example, there is the term "half-life competencies" - this time from graduation date until the time when competence is half reduced. It is established that after graduation $20 \%$ of knowledge get lost each year on average. Periods of knowledge obsolescence are distinguished by branches of science: in metallurgy this period is 3.9 years, mechanical engineering -5.2 years, chemical industry -4.8 years, etc. (Alekhina, 2003: 1).

In today's world volume of knowledge is constantly doubled over 10-15 years, in the long term rate of scientific and technical potential renewal reached such a level that they become obsolete 20 months later (Baeva, 2003: 2). In this regard, education system should be as mobile. Mobility of education system assumes control of retraining process to meet ever-expanding field of scientific knowledge. It requires active

(c) Siberian Federal University. All rights reserved

* Corresponding author E-mail address: mdlbuddy@mail.ru 
influence on overflow process of human capital from traditional industries to new ones.

Thus, economic approach to the problem lies in the fact that complexity of equipment due to scientific and technical potential complicates labor and creates the need for further training. This explains the need for lifelong learning. Here it is appropriate to quote the famous economist, T. Schultz, "The emergence of economists interest in education as a process of investing in human resources it is important to recall that formal training is no longer the sole and sufficient method of preparation of workforce. Diploma and working life are not the end of learning process but, as a rule, the end of its basic, preliminary stage and the beginning of a more specialized and lengthy process of acquiring professional development" (Dobrynin, 1993: 5).

Analysis of the literature allowed us to identify the following conditions and reasons for the development of lifelong learning concept:

- scientific, technical and social progress, which enhanced prestige of basic and vocational education;

- rapid growth of scientific information and its equally rapid aging, as a result it's not possible to give people knowledge in early life and for the rest of life;

- continuous change in technology and economics of production, transition to a postindustrial stage of social development, requiring constant professional development of workers and professionals;

- increase life expectancy and increase the proportion of elderly people among workers;

- distribution of Mass Media, which facilitated the possibility of obtaining information, etc;

- recognition of human increasing role in the production process associated with changing nature of work that requires creative and active attitude towards their work;

- public awareness of instrumental human value, tendency to provide people in all periods of their life with opportunities for self-development.

A variety of terms relating to lifelong learning, reflects different aspects of it. However, scientists dealing with "lifelong learning" have repeatedly stated that this term does not include a generally approved definition and there is a lack of clarity in terminology. According to research of G.D. Sorokoumova in international practice the most commonly used notions are the following: continuing education, lifelong education, permanent education, recurrent education, adult education, further education, post-graduate education, remedial education, etc.

According to UNESCO, in total there were about twenty of them. In different countries different terms are preferable: in the U.S. "lifelong learning", in England - "continuing education", in Sweden - "recurrent education". The latter term is also used the Organization for Economic Cooperation and Development (OECD), believing that "individual gets educated by parts throughout life" (Churekova, 2001: 6). The International Glossary of Education presented a dozen definitions of lifelong learning (Churekova, 2001: 6). Globally, it's realized that at the present stage of social development continuing education is primarily determined by the needs of an individual.

\section{Continuing Vocational Education Background}

Awareness of the problem of continuing education in Russia began in the mid-1960s, when social and economic conditions in the country have changed. During this period increases rate of technological progress, accompanied by 
continuous and significant changes in technology and economy of production, requiring continuous training of workers and specialists. In the middle and second half of 1970-s the first work on continuing education appeared in Soviet pedagogical literature.

The concept of "lifelong learning" was introduced in the Soviet pedagogy by Professor A. Darinsky (Darinsky, 1975: 4). He considers continuing education as an education system, a single, organizationally concerted that allows each person to develop, improve themselves throughout their lives in accordance with their aspirations and abilities.

V.G. Onushkin analyzing the essence of lifelong education concept, notes that it is based on the idea of connection in some form of vocational education or training with basic education at different levels. In the works of V.G. Onushkin and research of E.I. Ogarev it is noted that continuity of educational process should not be taken literally. If one looks specifically organized, premeditated training and education, then this process has always been and remains discrete. "Continuity as a scientific concept involves integrity of the system consisting of separate discrete elements" (Churekova, 2001: 6).

Since 1980-s "practical application" of lifelong education has been actively discussed. Before that they had only theoretical approach. Mainly in continuing education were regarded issues related to functioning of its particular components: basic education, vocational institutions, professional college, higher education, university extracurricular activities.

Domestic researchers A.P. Vladislavlev, V.A. Gorokhov, A.L. Zagorski, L.A. Kokhonova, E.I. Ogarev and V.G. Onushkin see the purpose of lifelong education concept in creation predictive models of educational process, providing a holistic and progressive nature of the development of all sides of personality. Also it should be noted that in domestic pedagogy role and place of selfeducation in continuing education of the Soviet period was clearly defined. Virtually all studies consider lifelong learning concept through the humanistic doctrines of lifelong human improvement when pedagogical approach is dominated over economic one.

Unlike domestic science Western scholars consider continuing education for a specific workplace or a firm and represent a process that begins after basic education (acting as a base) to further develop knowledge and skills.

Traditional education system was characterized by an individual that was educated once for the rest of his life. Currently education from the perspective of individual is regarded as lifelong learning - education "through life." For example, in Europe during the European Summit held in March 2000, was approved a memorandum "lifelong learning" (LLL) (Shlenov, 2005: 7). Slogan "education throughout life" was also declared by the UN (Volkov, 2004: 3). The idea of lifelong education lies in the Federal Law of "Higher and Postgraduate Professional Education" (Volkov, 2004: 3). Continuing education means purposeful and systematic growth of people's educational potential in their lifetime, obtained both in basic and professional education institutions, as well as due to selfeducation.

There nearly appeared continuous education system in Russia - from primary to postgraduate. Current continuing education system can be presented as a network of basic, vocational, vocational secondary and higher education, providing primary (basic) training, and structures operating in parallel, complementing basic form of training (training, retraining, etc).

Vocational education is a generic element of lifelong education, which is a network of educational institutions of different legal forms and types. The author states that vocational 
education system can be institutionally presented in the following form:

- system of educational institutions;

- enterprises and organizations conducting training and retraining of staff.

Educational institutions provide training on the basis of technical schools, colleges, universities; companies and organizations - on the basis of courses, interdisciplinary training centers, etc.

Every individual has a personal learning trajectory, which is a planned or spontaneous movement of a student, depending on his/her inclinations, abilities and requirements of careers. The concept of continuing professional education trajectory must pass through the entire life of a person, include formal (schools, technical schools, colleges, universities), non-formal (at workplace and at home) and latent (in family and community) learning. At the same time, formal education is supported by informal, which self-education (informal education) is related to. This support is that informal and self-education partially compensate for "gaps" in formal education. In a sense we can talk about establishing additional horizontal links in the formation of continuous education system. Formal and informal education should be equal participants in the process and, consequently, the results of education obtained as a set of individual competencies, should not only be taken into account, but also complement each other. This approach allows citizens to access knowledge as required or voluntarily.

Thus, continuing professional education is institutionally provided system of learning activities, adapted to new socio-economic conditions and aimed at improving knowledge, skills and abilities of a person throughout his life, which main factor is personal motivation and a variety of educational resources.

To learn continuously throughout life, each person in the first place, need positive learning experience at the young age, secondly, strong moral and material incentives, and thirdly, practical opportunities to learn - free time, money and facilities which provide educational services. Thus, during the life of each individual personal educational trajectory is formed - a purposeful process of obtaining the required level of knowledge by learners, including formal, informal and informal education as needed.

\section{Further Professional Education} as a part

\section{of Continuing Vocational Education}

One of the forms of continuing education is continuing professional education. Experts have already pointed out that in many Western countries, the rate of development of continuing vocational education exceeds the rate of development of traditional education system, as in continuing professional education one of the basic principles of education effectively performs: "necessary knowledge to right people at the right time."

Thus, the U.S. has a system of "continuing education", which is an important part of continuing education for adults, where the leading role is played by universities. In general, in the United States a third of all higher education institutions are actively engaged in continuing professional education. At the same time a lot of attention is paid to the links between schools and employers.

In the "continuing education" system of France an important role is played by National Association of Professional Adult Education. Its function is to regulate the labor market and adapt professionals to the changing demands of manufacturing.

The association includes about 130 training centers, some of which are engaged in educational research in the field of further education and preparation of curriculum. 
In the universities of the developed countries a lot of attention is paid to supplementary educational services to students.

Continuous education process involves active improvement and learning during the time of professional activity. Crucial significance for the development of continuous education is a firm that acts as an independent economic entity, characterized by its needs and interests.

Constantly increasing demand not only to skills directed to specific production processes, but also to the theoretical background. To achieve the synthesis of these two processes it is necessary an employee to be involved both in education and production systems. Therefore, the role of universities should not be underestimated, as they possess high intellectual, organizational, material and technical potential, which can be used for efficient provision of supplementary educational services for the public, enterprises and institutions. However, firms play an important role in the learning system of staff.

In the developed countries, most large companies and a growing number of small and medium clearly formulate the problem in the field of learning and support corporate and organizational development. In many enterprises, job training and staff development programs are becoming an integral part of corporate and organizational strategy. This also applies to companies that produce products or services with high added value.

The basis of interaction between education and manufacture - capital investment of firms in the development of universities in different ways: financing, equipment and machinery supply, etc. Over the past 20 years in the U.S. firms provision for higher education institutions increased by 20 times.

Interaction program between universities and companies involve not only the exchange of experience, but also, equally important, involvement of employees of enterprises as teachers or consultants, including part-time job. This is especially true in areas where firms' technologies surpass knowledge of high school teachers. Often skilled craftsmen of the firms act as students' mentors during the internship. When writing Master and doctoral papers one of the supervisors is often a researcher of the firm or leading research engineer. And vice versa, in the education centers of the companies are involved high school staff. Firms presenting their claims should be involved in the adjustment process of educational curricula, concerning replacement and inclusion of additional subjects as well.

Thus, role of the firm should not be underestimated and its absence in considered concept does notallow evaluating the effectiveness of the education system as a whole: "Human capital is created by firms because they often serve as the most efficient producers of capital" (Baeva, 2003: 2).

Russia now has embarked on an innovative path of development, so the underlying asset is human capital, which includes, above all, such accountable items as level of education and skills, but the determining factor in the production become knowledge. It is no mere chance that in today's society continuing professional education is associated with information economy, economy based on knowledge.

Economy based on knowledge, marks the transition from industrial to postindustrial society, which is associated with the development of Information, Communication and Intelligent efficient Technologies (digital, bio-, nano-, etc.). Postindustrial society, in turn, includes three interrelated entities:

1) society based on knowledge;

2) information society; 
3) learning society, that fulfils itself in the process of learning throughout life.

Society based on knowledge is characterized by increasing investment in high technology, development of high-tech industries and availability of skilled labor force.

Development of new information, economic, social, legal, political and cultural areas in the country caused an increased need for a variety of trades and professions, constant upgrading of existing professional knowledge and skills, their willingness to re-qualification and acceptance of innovative technologies and forms of professional activity. There is a real opportunity to develop the latest scientific achievements in various fields of professional activity.

Russian reality today is that system of continuing professional education should perform not only cultural but also social, economic mission. Development of continuing vocational education in our country at present is largely opportunistic in nature, caused by dramatic changes that have occurred in recent years. In Russia there are over three thousand educational institutions and structural units of continuing professional education (Volkov, 2004: 3). But, unfortunately, there is no law of continuing vocational education.

Further development of vocational education is impossible without improving its legal framework for the corresponding to new economic and social conditions. This confirms experience of the developed Western countries. Thus, in France in 1971 a law of education, continuous training and retraining was enacted; in Sweden in 1975 - law of education system restructuring, which is based on the idea of continuing education; in the U.S. in 1976 - an act of lifelong learning. The state not only declares the need for training and education of all workers, but also finances these processes.

\section{Conclusion}

The main principles of the concept of continuing professional education in our country should be:

1. Expansion of organizations list offering more vocational programs. Experience has shown that in education may be involved, for example, large commercial entities (companies) who have material resources to implement any continuing professional programs, including inhouse training.

2. Expansion and clarification of certain types of continuing educational programs assigned by law, due to the dynamic changes in the educational market in "new economy" and need for constant updating of educational programs and services in general.

3. Reforming various aspects of Russian life. This applies to changes in personnel policy in the labor market, enhancement of market participants' educational services, intention of Russia to turn to innovative way of development, etc.

4. Allocation of responsibility among the participants, when society creates a demand for educational services, provider determines their size, quality and price, and the state controls and partially defines the processes in the system, as an equal participant in the market.

5. Continuing professional education must be seen as a system being a single complex with economy and labor market, which should provide positive feedback: educational institution enterprise. This will help develop "leading" educational programs that meet the demands of the labor market, society and international standards.

In the present circumstances when a leading social group becomes intellectual workers, in the field of training and retraining specialists increases the role of universities that have qualified teaching staff and necessary for 
educational process material, technical and information support.

Enterprises and organizations, in turn, must act as active agents in the labor market by means of the creation requirements for the training, participation in the development of educational programs, organization of in-house training.
The basis of continuing professional education shall be: integration (coverage of the whole life period), democracy (equal access to education), universality (union of the various educational stages and structures) and flexibility (use of various forms, means and methods of teaching).

\section{References}

1. G.P. Alekhina, National models of employment and job market (Tomsk: Tomsk State University, 2003) (In Russian).

2. Baeva, Continuing education as a condition for human capital development. Candidate Dissertation (Moscow: Russian State Library, 2003) (In Russian).

3. Yu.G. Volkov, "Continuing professional education - a new social institution in Russia", Social sciences and humanities, Issue 3 (Moscow, 2004), p. 197-207. (In Russian).

4. A.V. Darinsky, "Continuing education", Soviet pedagogy, Issue 1 (Moscow, 1975), p. 16-25 (In Russian).

5. A. Dobrynin, S. Dyatlov, V. Konkov, S. Kurgansky, Productive forces of man (St. Petersburg.: Publishing House SPbUEF, 1993) (In Russian).

6. T.M. Churekova, Continuing education and personal development in the innovative education: Ed. by N.E. Kasatkina (Kemerovo: Kuzbassvuzizdat, 2001) (In Russian).

7. Yu. Shlenov, I. Mosicheva, V. Shestak, "Continuing Education in Russia", Higher education in Russia, Issue 3 (Moscow, 2005), p.36-49. (In Russian). 


\title{
Значение дополнительного \\ профессионального образования \\ в системе непрерывного \\ профессионального образования
}

\author{
Д.Л. Матухин \\ Национальный исследовательский \\ Томский политехнический университет \\ Россия, 634050, Томск, пр. Ленина, 30
}

\begin{abstract}
Статья посвящена проблемам непрерывного профессионального образования. Оно рассматривается с позиции отечественного и западного понимания концепции непрерывного образования. Развитие системы дополнительного профессионального образования как составной части непрерывного профессионального образования является весьма актуальнылм для России. Это обусловлено конъюнктурныли изменениями в кадровой политике на рынке труда, динамичными изменениями на рынке образовательных услуг, информатизаиией общества и стремлением России стать на инноваџионный путь развития.
\end{abstract}

Ключевые слова: дополнительное профессиональное образование, непрерывное профессиональное образование, человеческий капитал, рынок труда, повымение квалификации.

Научная специальность: 10.00.00 - филологические науки. 